\title{
Functional domains within FEN-1 and RAD2 define a family of structure- specific endonucleases: implications for nucleotide excision repair
}

\author{
John J. Harrington and Michael R. Lieber ${ }^{1,2}$ \\ Laboratory of Experimental Oncology, Department of Pathology, Stanford University School of Medicine, Stanford, \\ California 94305-5324 USA
}

\begin{abstract}
Structure-specific nucleases catalyze critical reactions in DNA replication, recombination, and repair. Recently, a structure-specific endonuclease, FEN-1, has been purified and shown to cleave DNA flap structures. Here, we describe the cloning of the murine $F E N-1$ gene. The nucleotide sequence of FEN-1 is highly homologous to the Saccharomyces cerevisiae genes YKL510 and RAD2. We show that YKL510 and a truncated RAD2 protein are also structure-specific endonucleases. The substrate specificity of the truncated RAD2 protein implicates branched DNA structures as important intermediates in nucleotide excision repair. The polarity of these branched DNA structures allows us to predict the placement of DNA scissions by RAD2 and RAD1/RAD10 in this reaction.
\end{abstract}

[Key Words: FEN-1; RAD2; YKL510; nuclease; nucleotide excision repair; structure specific]

Received March 16, 1994; revised version accepted April 21, 1994.

Nucleotide excision repair (NER) is a major pathway by which damaged nucleotides are removed from DNA (Prakash et al. 1993). The importance of this pathway is illustrated by xeroderma pigmentosum, a human genetic disorder resulting in defects in NER. This disease is characterized by severe sensitivity to sunlight and a predisposition to the development of skin cancer. Mutations in the excision repair genes of Escherichia coli, yeast, and other mammalian cells result in a similar hypersensitivity to UV radiation.

The biochemical steps leading to the repair of damaged DNA bases include recognition of damage, incision and removal of the damaged strand, DNA synthesis to replace the excised nucleotides, and ligation. Genetic studies in yeast have identified seven repair genes that are absolutely required for the initial DNA incisions to occur. These genes have been shown to encode nucleases (RAD1/10 and RAD2) (Habraken et al. 1993; Tomkinson et al. 1993), helicases (RAD3 and RAD25) (Sung et al. 1987; Harosh et al. 1989; Gulyas and Donahue 1992; Park et al. 1992), and a damage recognition protein (RAD14) (Guzder et al. 1993). Because RAD1, RAD2, RAD3, RAD10, and RAD25 show no preference for damaged DNA, it is thought that they are localized to the site

\footnotetext{
${ }^{1}$ Corresponding author.

${ }^{2}$ Present address (as of August 1, 1994): Division of Molecular Oncology, Departments of Pathology and Biochemistry, Washington University School of Medicine, St. Louis, Missouri 63110 USA.
}

of damage through interactions with a damage recognition protein such as RAD14. Experimental evidence for interactions among RAD proteins now exists (Sung et al. 1987; Bailly et al. 1992; Bardwell et al. 1992, 1994; Feaver et al. 1993; van Vuuren et al. 1993). However, it is not clear how these enzymes work together to incise and remove the oligonucleotide excision tract containing the damaged bases. Current models hypothesize that the RAD3 and RAD25 helicases act together to set up specific branched DNA structures at the site of damage. The resulting branched DNA structures may then be cleaved by the single-stranded endonucleases, RAD1/10 and RAD2.

The design of branched DNA structures similar to those hypothesized in NER have allowed the purification of a mammalian DNA structure-specific endonuclease (Harrington and Lieber 1994). This enzyme, called Flap endonuclease-1 or FEN-1, cleaves DNA flap strands that terminate with $5^{\prime}$ single-stranded ends (see structure in Fig. 1). FEN-1 cleavage is flap strand specific and independent of flap strand length. Other branched DNA structures, including Holliday junctions, are not cleaved by FEN-1. In addition to endonuclease activity, FEN-1 has a $5^{\prime}-3^{\prime}$ exonuclease activity that is specific for double-stranded DNA. On the basis of these activities, it has been suggested that FEN-1 may be involved in replicative and repair DNA synthesis through a nick translation mechanism (Harrington and Lieber 1994).

To gain insight into the biological function of FEN-1, 


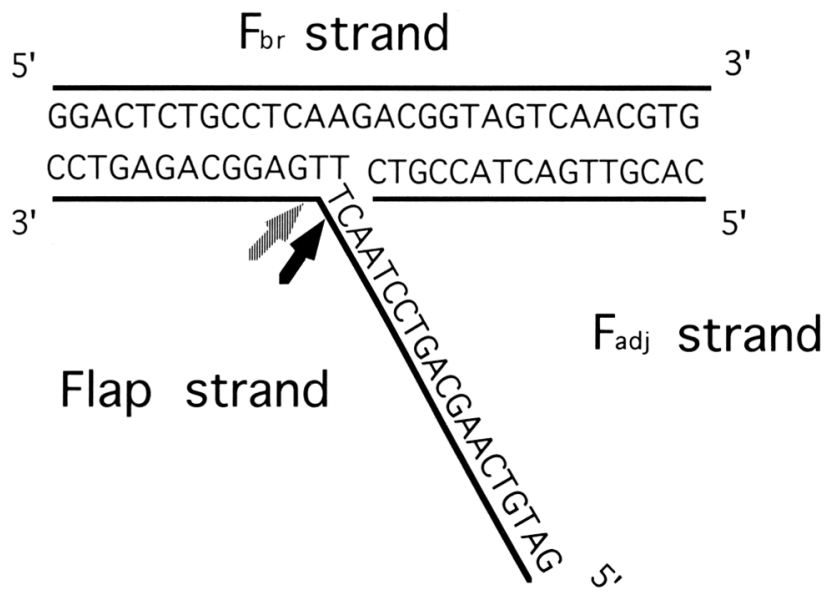

Figure 1. DNA substrate for flap cleavage. Nucleotide sequence for each of the three oligonucleotides that make up flap substrate 1 is shown. The flap strand $(\mathrm{HI} 42)$ was $5^{\prime}$-end-labeled and annealed to the $\mathrm{F}_{\mathrm{br}}(\mathrm{HJ} 41)$ and $\mathrm{F}_{\mathrm{adj}}(\mathrm{HI} 43)$ strands as described in Materials and methods. The solid lines above and below this structure are shown to illustrate continuous strands. Following incubation of flap substrate 1 with protein extract, the reaction products are separated from the 34-nucleotide input on a denaturing polyacrylamide gel. The preferred cut sites of FEN-1 are located 1 nucleotide proximal (hatched arrow) and 1 nucleotide distal (solid arrow) to the elbow of the flap strand.

we have cloned the gene that encodes this nuclease. The amino acid sequence of FEN-1 is highly homologous to the RAD2 protein family (Carr et al. 1993; MacInnes et al. 1993; Scherly et al. 1993). We show further that two members of this family, YKL510 and a truncated form of RAD2, are structure-specific endonucleases similar to FEN-1. Our results establish DNA flap structures as important substrates in DNA metabolism, particularly in NER. In addition, the exact substrate specificities of RAD2 described here have allowed us to make precise mechanistic predictions relating to the placement of DNA scissions by RAD1/10 and RAD2 during NER.

\section{Results}

\section{Cloning and analysis of the murine FEN-1 gene}

DNA flap substrate 1 was designed to detect structurespecific endonucleases in mammalian cells (Fig. 1). This substrate is a $5^{\prime}$ flap structure because the flap strand terminates with a $5^{\prime}$ single-stranded end. Conversely, $3^{\prime}$ flap structures have a flap strand that terminates with a $3^{\prime}$ single-stranded end. Both $5^{\prime}$ and $3^{\prime}$ flap structures are composed of a flap strand, an $\mathrm{F}_{\mathrm{br}}$ (bridge) strand, and an $F_{\text {adj }}$ (adjacent) strand. Previously, we identified and purified a mammalian structure-specific endonuclease, called FEN-1, which specifically cleaves $5^{\prime}$ flap structures but not $3^{\prime}$ flap structures. Cleavage of flap substrate 1 occurs primarily at 1 nucleotide proximal and 1 nucleotide distal to the elbow of the flap strand. Other 5 ' flap structures, however, are cleaved by FEN-1 primarily at 1 nucleotide proximal to the flap strand elbow.
We have microsequenced tryptic fragments of purified murine FEN-1 and used this amino acid sequence to design degenerate oligonucleotide probes. An initial screen of 300,000 plaques from a mouse thymocyte cDNA library yielded eight positive clones that were related by restriction digest. The largest clone was $2.1 \mathrm{~kb}$ and produced a protein of the expected molecular weight when transcribed and translated in vitro (data not shown).

The FEN-1 cDNA insert was subcloned into the $E$. coli expression vector, PET 11d (Studier et al. 1990) to create PET-FEN. On induction, cells containing PET-FEN, but not PET 11d, produced a soluble $50-\mathrm{kD}$ protein /data not shown). In addition, extracts from cells containing PETFEN specifically cleaved a $5^{\prime}$ flap structure, whereas extracts from cells containing PET 11d did not (Fig. 2A). Cleavage of the flap substrate occurred near the elbow of the displaced flap strand and resulted in labeled products that were 17-23 nucleotides in length. Using a modification of the purification procedure described previously (Harrington and Lieber 1994), recombinant FEN-1 was purified to a single band on a Coomassie-stained SDSpolyacrylamide gel (Fig. 2B).

To confirm that the above cDNA clone encodes FEN1 , the purified recombinant FEN-1 (fraction V) was compared with FEN-1 that was purified previously from mouse lymphocytes. The enzymatic activities and specificities of these two enzyme preparations were identical (Fig. 3A,B). Recombinant FEN-1 cleaved three different 5 ' flap structures and had $5^{\prime}-3$ ' double-strand-specific exonuclease activity but did not cleave $5^{\prime}$ pseudo-Y structures or single-stranded DNA. A 5' pseudo-Y structure is a $5^{\prime}$ flap structure that is missing the $F_{\text {adj }}$ strand. In addition, both enzyme preparations failed to cleave $3^{\prime}$ flap structures.

By Western blot, antibodies generated against recombinant FEN-1 (fraction V) recognize FEN-1 purified from lymphocytes (data not shown). These antibodies also inhibit murine lymphocyte FEN-1 nuclease activity when present in the reaction, whereas control antibodies do not (Fig. 3C). Taken together, these results clearly indicate that the cDNA clone described below encodes FEN-1.

\section{FEN-1 is homologous to the RAD2 protein family}

The nucleotide sequence of $F E N-1$ revealed an open reading frame of $1134 \mathrm{bp}$ (Fig. 4). The amino acid sequence of this putative polypeptide was found to be highly homologous to the RAD2 protein family (Fig. 5A). The strongest homology was found between FEN-1 and YKL510 (Jacquier et al. 1992), an open reading frame in Saccharomyces cerevisiae with previously unknown function. In addition to being the same size, FEN-1 and YKL510 were $60 \%$ identical ( $78 \%$ similar) at the amino acid level. FEN-1 was also found to be equally homologous in sequence and structure to the Schizosaccharomyces pombe Rad2 gene (Lehmann et al. 1991; Carr et al. 1993) (data not shown). It has been suggested previously that $S$. pombe Rad2 is the analog of S. cerevisiae YKL510 (Lehmann et al. 1991; Carr et al. 1993). The homology de- 


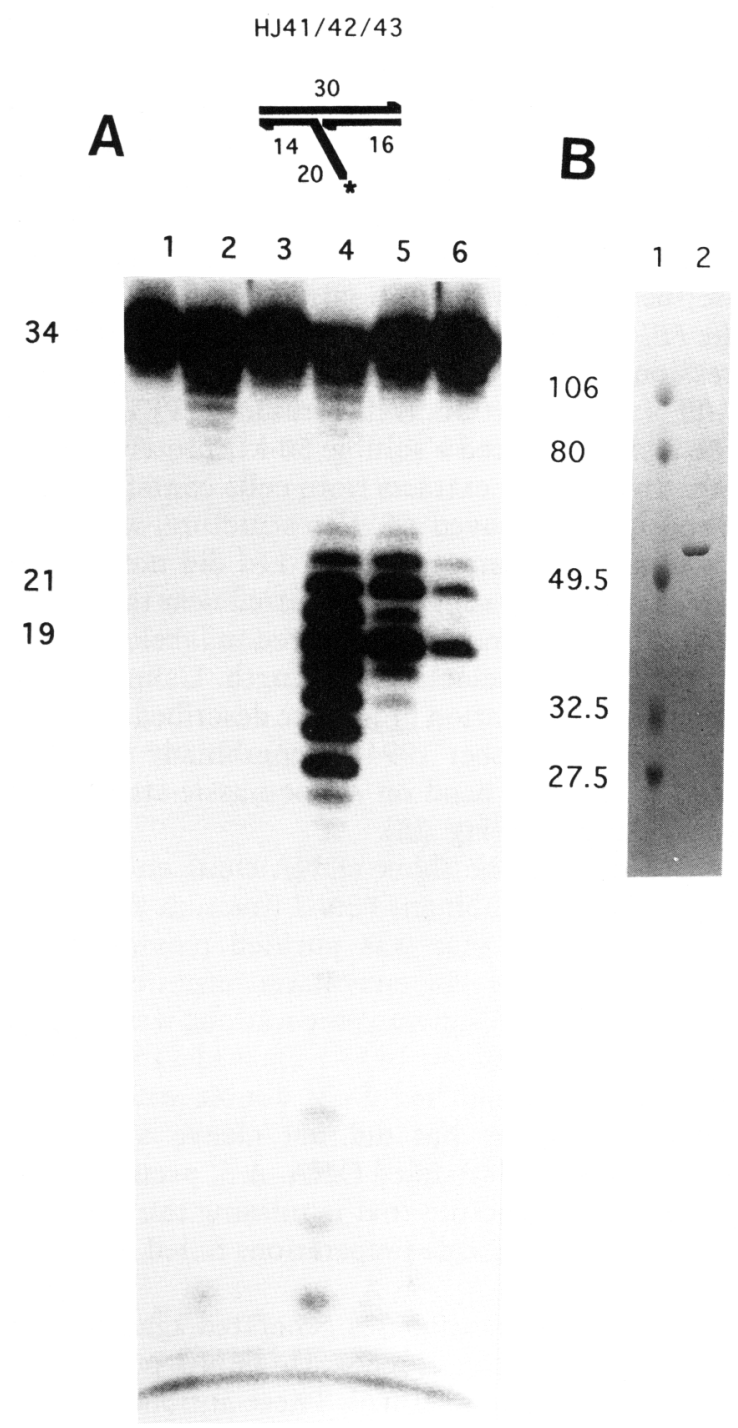

Figure 2. Biochemical characterization of cloned FEN-1. $(A)$ Crude extracts from $E$. coli lacking FEN-1 (PET vector) or expressing FEN-1 (PET-FEN) were assayed for flap cleavage activity on flap substrate 1 , which is shown schematically at the top. The asterisk indicates the position of the radioactive label. Reactions contained $1 \mu \mathrm{g}$ of salmon sperm DNA as competitor. (Lane 1) No extract; (lanes 2,3) 30 and 3 ng of PET vector extract, respectively; (lanes $4,5,6) 30,3$, and 0.3 ng of PET-FEN extract, respectively. $(B)$ Purified recombinant FEN-1 was analyzed on a reducing $10 \%$ SDS-polyacrylamide gel. (Lane 1) Bio-Rad prestained molecular weight markers; (lane 2) $1 \mu \mathrm{g}$ of purified recombinant FEN-1 (fraction V). Following electrophoresis, the gel was stained with Coomassie R-250. Molecular weight markers are shown in nucleotides (DNA gels) or in kilodaltons (protein gels) at left.

scribed here suggests that FEN-1 is the mammalian analog of these two yeast proteins.

Significant homology also was found between FEN-1 and regions within $S$. cerevisiae RAD2, termed N, I, and C (Fig. 5A). Previous studies have shown that the N, I, and $\mathrm{C}$ regions are also highly conserved in $\operatorname{Rad} 13$ and
XP-G, the $S$. pombe and human analogs of $S$. cerevisiae RAD2 (Carr et al. 1993; Scherly et al. 1993). FEN-1 is $41 \%$ and $28 \%$ identical $(60 \%$ and $51 \%$ similar) to $S$. cerevisiae RAD2 in the $\mathrm{N}$ and I regions, respectively (Fig. $5 \mathrm{~B})$. The $\mathrm{C}$ region, on the other hand, is conserved in structure rather than sequence. This highly basic carboxy-terminal tail is present in each of the RAD2 family members.

One difference within the RAD2 family is that the $\mathrm{N}$ and I regions are separated to varying extents. In FEN-1 and YKL510, these regions are separated by $\sim 15$ amino acids, whereas in RAD2, this separation is over 600 amino acids. We have designated this intervening sequence the S-region (spacer) until the function of this domain is elucidated. This structural difference between these two subsets of proteins will likely give insight into their respective roles in DNA metabolism.

\section{S. cerevisiae YKL510 is functionally analogous to FEN-1}

On the basis of the high degree of conservation between FEN-1 and YKL510, it is likely that YKL510 is the yeast analog of FEN-1. To test this, we cloned the YKL510 gene into PET $11 \mathrm{~d}$ and expressed it in $E$. coli. We found that extracts from cells containing PET-YKL specifically cleaved a $5^{\prime}$ flap structure, whereas extracts from cells containing PET 1ld were inactive on this substrate (Fig. 6A). Using the standard flap cleavage assay to monitor chromatographic behavior, recombinant YKL510 was purified from $E$. coli and found to migrate as a $49 \cdot \mathrm{kD}$ band on SDS-PAGE (Fig. 6B). As a control, extract from cells containing PET 11d was purified in exactly the same way as YKL510 and is designated PET (fraction V). No protein could be detected in this fraction on a Coomassie-stained SDS-polyacrylamide gel (data not shown). In addition, PET (fraction V) was found to be devoid of nuclease activity (Fig. 6C,D).

Analysis of substrate specificity revealed that purified YKL510 cleaved 5' flap structures but not a 3' flap structure or single-stranded DNA (Fig. 6C, lanes 1-6, 13-18). Like FEN-1, YKL510 efficiently cleaved 5 ' flap structures independent of flap strand length (Fig. 6C, lanes 1-6, $10-12$ ) and failed to cleave $5^{\prime}$ pseudo-Y structures (Fig. 6C, lanes 7-9). In addition, YKL510 was found to have 5 ' -3 ' double-strand-specific exonuclease activity similar to that of FEN-1 (Fig. 6D). The product of YKL510 exonuclease activity was mono- and dinucleotides as determined by high percentage sequencing gels. The similar sequence, structure, and enzymatic activities of these two enzymes indicates that YKL510 is the yeast analog of FEN-1.

\section{Domains within RAD2 are capable of cleaving DNA flap structures}

RAD2 is homologous to FEN-1 and YKL510 in three major regions (Fig. 5). The separation of the $\mathrm{N}$ and I regions by the $\mathrm{S}$ region in $\mathrm{RAD} 2$, however, represents one differ- 


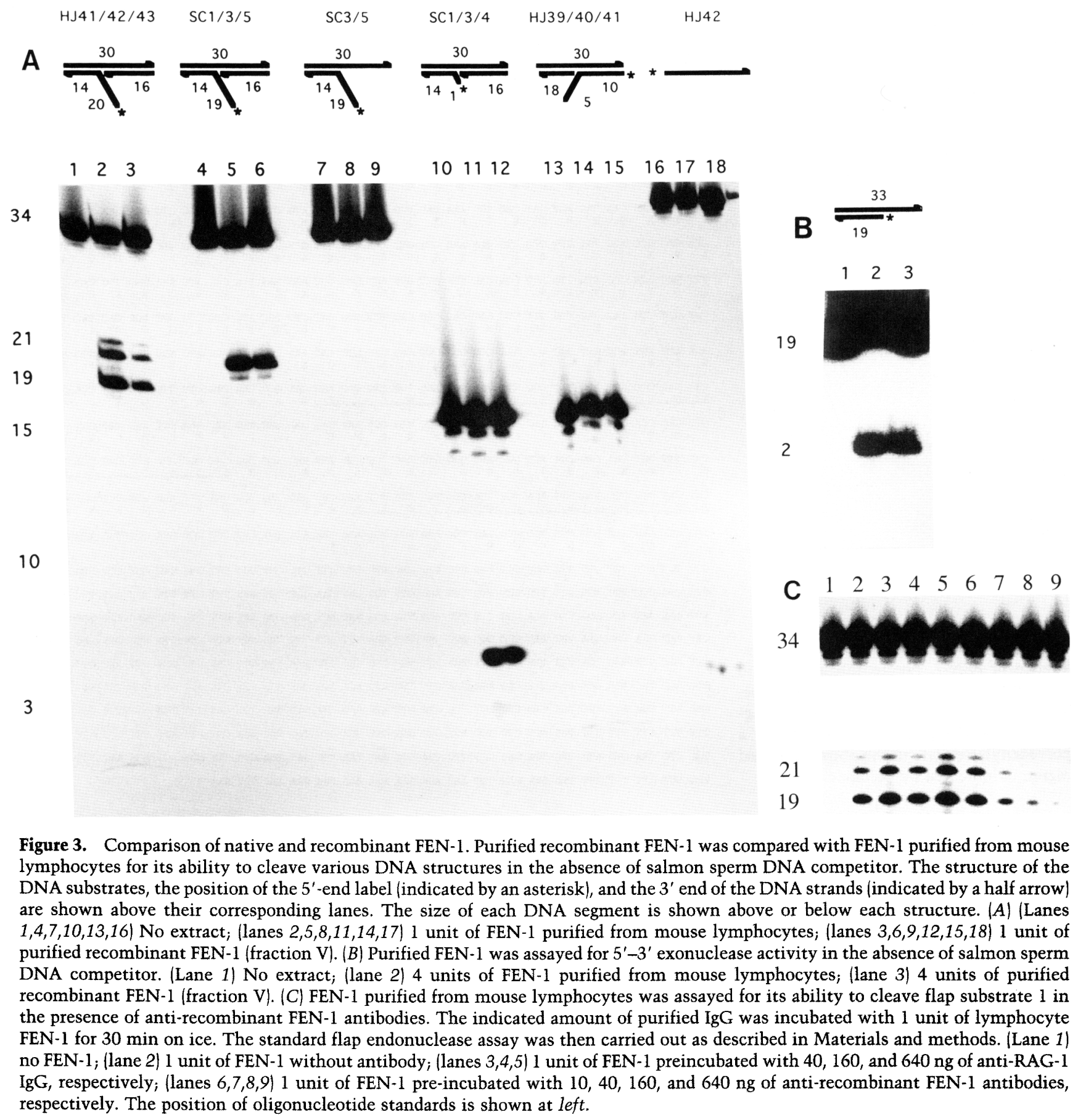

ence between these two RAD2 family subtypes. Because both FEN-1 and RAD2 have been shown to be nucleases, it is likely that the DNA-binding domain and active site of these enzymes lie within one of these regions of homology. To determine whether the S region of RAD2 can be deleted to give a truncated $R A D 2$ protein that is still a functional nuclease, the $R A D 2$ gene was modified to produce $\triangle R A D 2$ (Fig. $7 \mathrm{~A}$ ). Expression of $\triangle R A D 2$ from PET 11d produced a $5^{\prime}$ flap cleavage activity that was absent in extracts from cells containing PET 11d /Fig.
7B). $\triangle \mathrm{RAD2}$ was purified by use of the standard flap assay to monitor its chromatographic behavior. As a control, a side-by-side purification of extracts from cells containing PET 11d was carried out. On a silver-stained SDS-polyacrylamide gel, $30 \mathrm{ng}$ of $\triangle \mathrm{RAD} 2$ (fraction V) contained one $53-\mathrm{kD}$ band, the expected size of $\triangle \mathrm{RAD} 2$ (data not shown). To further ascertain purity; purified PET (fraction V) was assayed for nuclease activity. Despite using 20-fold more PET (fraction V) than is required for 1 unit of $\triangle \mathrm{RAD} 2$ activity, we were unable to detect 
Figure 4. Nucleotide and amino acid sequence of $F E N-1$. Nucleotide and amino acid sequences of FEN-1 are shown. Regions corresponding to FEN-1 tryptic frag. ments are underlined. The location of a polyadenylation site in the 3 '-untranslated region is indicated by boldface type.

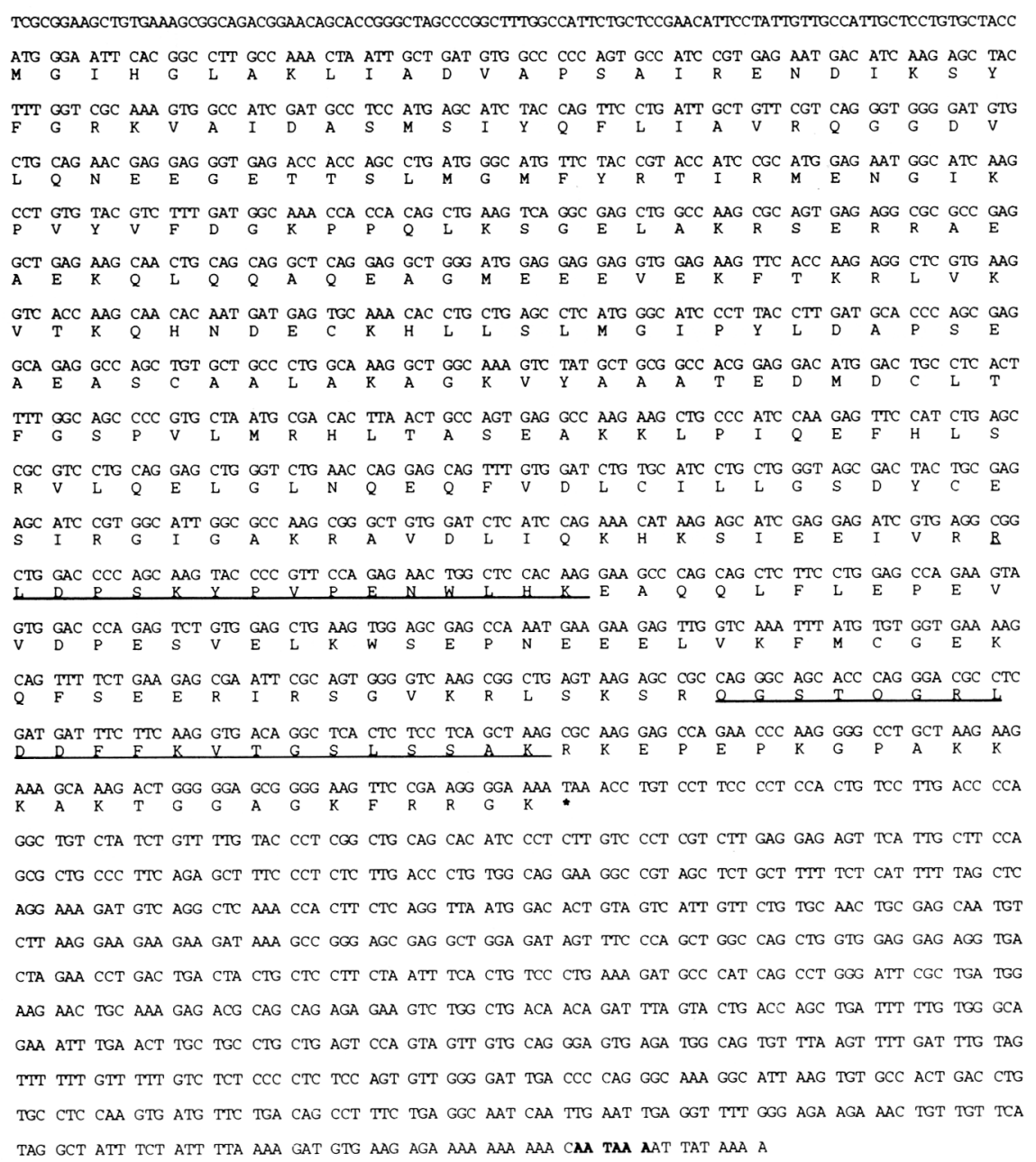

contaminating nuclease activity /data not shown and Fig. $7 \mathrm{C}, \mathrm{D})$.

Recently, Habraken et al. demonstrated that RAD2 is a single-stranded endonuclease based on its ability to cleave M13 single-stranded circles /Habraken et al. 1993). Unlike M13 DNA, which has undefined secondary structure, the sequence and structures of the substrates used here are well defined. These substrates, therefore, have allowed us to ask specifically which structures are cleaved and where that cleavage is occurring. We analyzed the substrate specificities of purified $\triangle \mathrm{RAD} 2$ and found that it was a structure-specific endonuclease that cleaves $5^{\prime}$ flap structures but not $3^{\prime}$ flap structures (Fig. 7C, lanes 1-6, 10-15). Like FEN-1 and YKL510, $\triangle$ RAD2 also did not cleave $3^{\prime}$ pseudo-Y structures (data not shown). A $3^{\prime}$ pseudo-Y structure is a $3^{\prime}$ flap structure that is missing the $F_{\text {adi }}$ strand (see structure in Fig. $8 \mathrm{D}$ |. Interestingly, $\triangle \mathrm{RAD} 2$ did cleave $5^{\prime}$ pseudo-Y structures (Fig. 7C, lanes 7-9).

$\triangle$ RAD2 differed from FEN-1 and YKL510 in its ability to act as a $5^{\prime}-3^{\prime}$ double-strand specific exonuclease. FEN-1 and YKL510 exonuclease activities were approximately half as efficient as their respective DNA flap cleavage activities. $\triangle \mathrm{RAD} 2$, on the other hand, had only a weak $5^{\prime}-3^{\prime}$ exonuclease activity that was 100 times less efficient relative to its flap cleavage activity (Fig. 7D). Thus, the primary activity of $\triangle \mathrm{RAD} 2$ appears to be endonucleolytic in nature.

Finally, $\triangle \mathrm{RAD} 2$ did not cleave single-stranded DNA oligonucleotides (Fig. 7C, lanes 16-18). Although $\triangle \mathrm{RAD2}$ is most active on flap structures, cleavage of pseudo-Y structures is easily detected in our assay. Because pseudo-Y structures have been shown to be present in M13 DNA at sites of inverted repeats, RAD2 may be cleaving M13 DNA at sites of secondary structure rather than regions of single-stranded DNA. The implications of this structure-specific cleavage are discussed below.

\section{Discussion}

In this study we have cloned the murine $F E N-1$ gene. This is the first characterized DNA structure-specific endonuclease to be cloned from any eukaryote. Interestingly, FEN-1 is highly homologous to the RAD2 protein family. Within this family, we show that this structural homology can be extended to functional homology as well. Two members of the RAD2 protein family, 

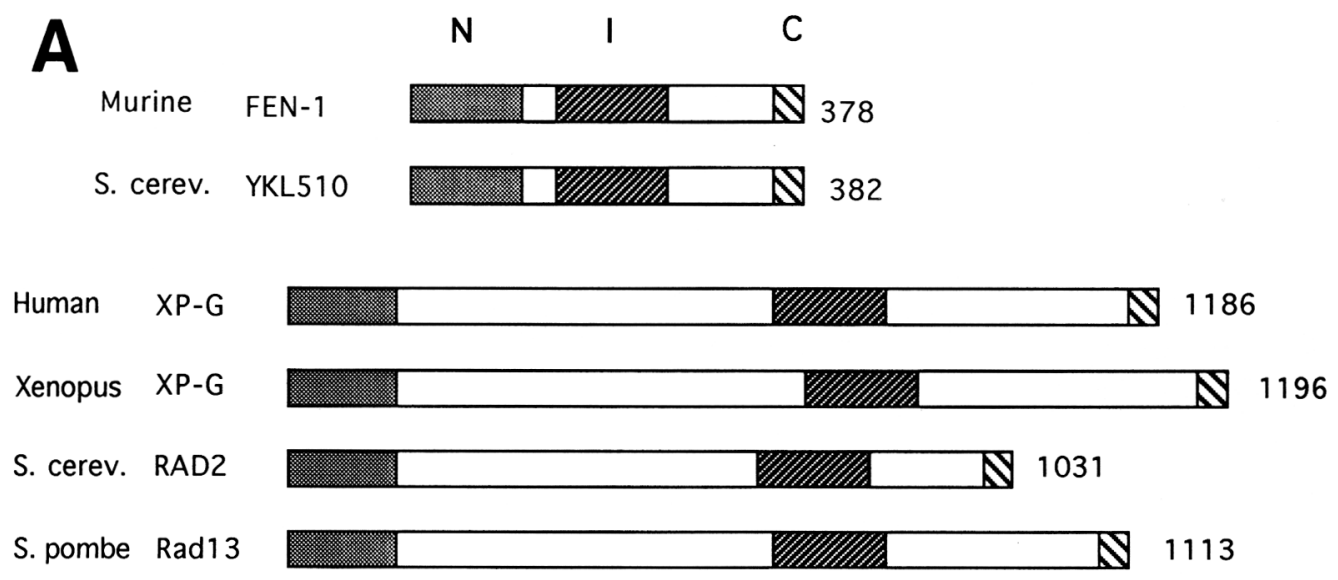

B

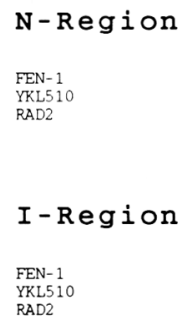

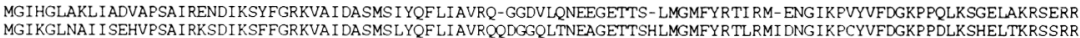

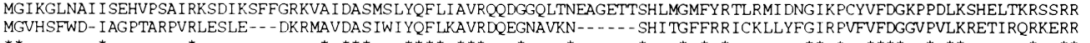

EVEKFTKRLVKVTKQHNDECKHLLSLMGI PYLDAPSEAEASCAALAKAGKVYAAATEDMDCLTFGSPVLMRHLTASEAKKLP IQEFHLSRVLQELGLNQEQFVDLCI LLGSDYCESI RGIGAKRAVDLIQKHKSIEE I EKMKQERRLVKVSKEHNEEAQKLLGLMGI PYI IAPTEAEAQCAELAKKGKVYAAASEDMDTLCYRTPFLLRHLTFSEAKKEP I HEI DTELVLRGLDLTIEQFVDLCIMLGCDYCESI RGVGPVTALKLI KTHGSIEK

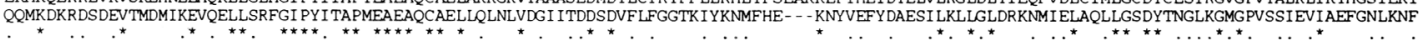

C-Region

$\begin{array}{ll}\text { FEN-1 } & \text { KRKEPEPKGPAKKKAKTGGAGKFRRGK } \\ \text { YKL510 } & \text { KRAQENKKLNKNKNKVTKGRR }\end{array}$

$\begin{array}{ll}\text { YKL510 } & \text { KRAQENKKLNKNKNKVTKGRR } \\ \text { RAD2 } & \text { KKLNTSKRISTATGKLKKRKM }\end{array}$

$\begin{array}{ll}378 & (12 \mathrm{ARG}+\text { LYS }) \\ 382 & (10 \mathrm{ARG}+\mathrm{LYS}) \\ 1031 & (9 \mathrm{ARG}+\mathrm{LYS})\end{array}$

Figure 5. Relationship between FEN-1 and the RAD2 protein family. (A) A schematic representation of FEN-1 and the RAD2 family of proteins is shown to illustrate regions of homology. The highest degree of homology lies in three regions designated $\mathrm{N}$, I, and $\mathrm{C}$ regions, which are indicated by hatch marks. $(B)$ Amino acid sequences from the $N$, I, and C regions of the RAD2 protein family are aligned to identify conserved amino acids. The numbers at right correspond to the amino acid position of the last amino acid in that segment. The asterisks located under the amino acids indicate positions of identity, whereas dots indicate positions with conservative changes.

YKL510 and a truncated form of RAD2, are structurespecific endonucleases. All three enzymes cleave 5 ' flap structures and fail to cleave other DNA structures, including 3' flaps and single-stranded DNA. Unlike FEN-1 and YKL510, $\triangle$ RAD2 efficiently cleaves $5^{\prime}$ pseudo-Y structures and has only a weak exonuclease activity when compared with its flap endonuclease activity. By analogy, the other members of the RAD2 family, including $S$. pombe Rad2 and Rad13 and human XP-G, are likely to be structure-specific endonucleases as well.

We have hypothesized that FEN-1 is involved in the removal of Okazaki fragment primers during replication and in the removal of damaged bases from DNA (Harrington and Lieber 1994). This idea is supported by work done in bacterial systems. E. coli DNA polymerase I has been shown to be involved in DNA replication and DNA repair (Baker and Kornberg 1992). The intrinsic 5'-3' exonuclease domain of DNA polymerase I ( $\mathrm{Pol} \mathrm{I}$ ) has been shown to be absolutely required for both of these functions. In addition, the $5^{\prime}-3^{\prime}$ exonuclease domain has been shown to be a structure-specific endonuclease that cleaves 5' flap structures (Lyamichev et al. 1993). Eukaryotic polymerases, however, do not have an intrinsic $5 '-3$ ' exonuclease domain. It has been proposed that this activity is localized to the replication fork by proteinprotein interactions with DNA polymerase $\epsilon$ (Siegal et al. 1992). Interestingly, DNA polymerase $\epsilon$ (Pol $\epsilon$ ) has also been shown to be involved in the repair of UV-damaged DNA (Wang et al. 1993). Recently, it has been shown that the calf thymus $5^{\prime}-3^{\prime}$ exonuclease also is a flap endonuclease that interacts functionally with DNA Pol $\epsilon$ (Murante et al. 1994). On the basis of the size and enzymatic properties of this enzyme, it is likely to be the bovine analog of murine FEN-1. Thus, the DNA Pol $\epsilon / F E N-1$ complex may be the eukaryotic counterpart to E. coli DNA Pol I. The identification of YKL510 as the yeast analog of FEN-1 will allow us, through the use of genetics, to test this hypothesis.

Despite almost identical biochemical activities, the DNA repair activity of RAD2 apparently cannot be com- 
34

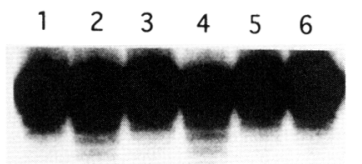

21

19
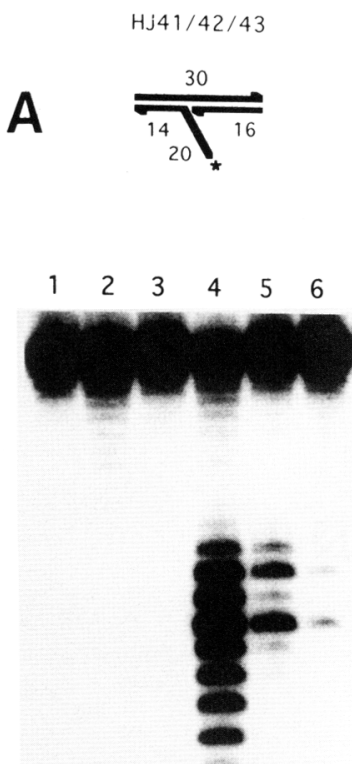

21

19

15

10
34

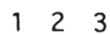

$\mathrm{SC} 1 / 3 / 5$

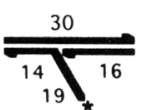

456

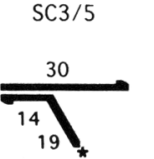

$\mathrm{SC} 1 / 3 / 4$

$\mathrm{HJ} 39 / 40 / 41$

$\begin{array}{lll}7 & 8 & 9\end{array}$

101112

131415

161718

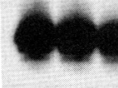

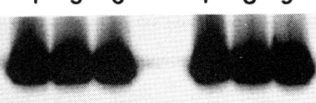

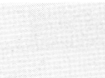

.
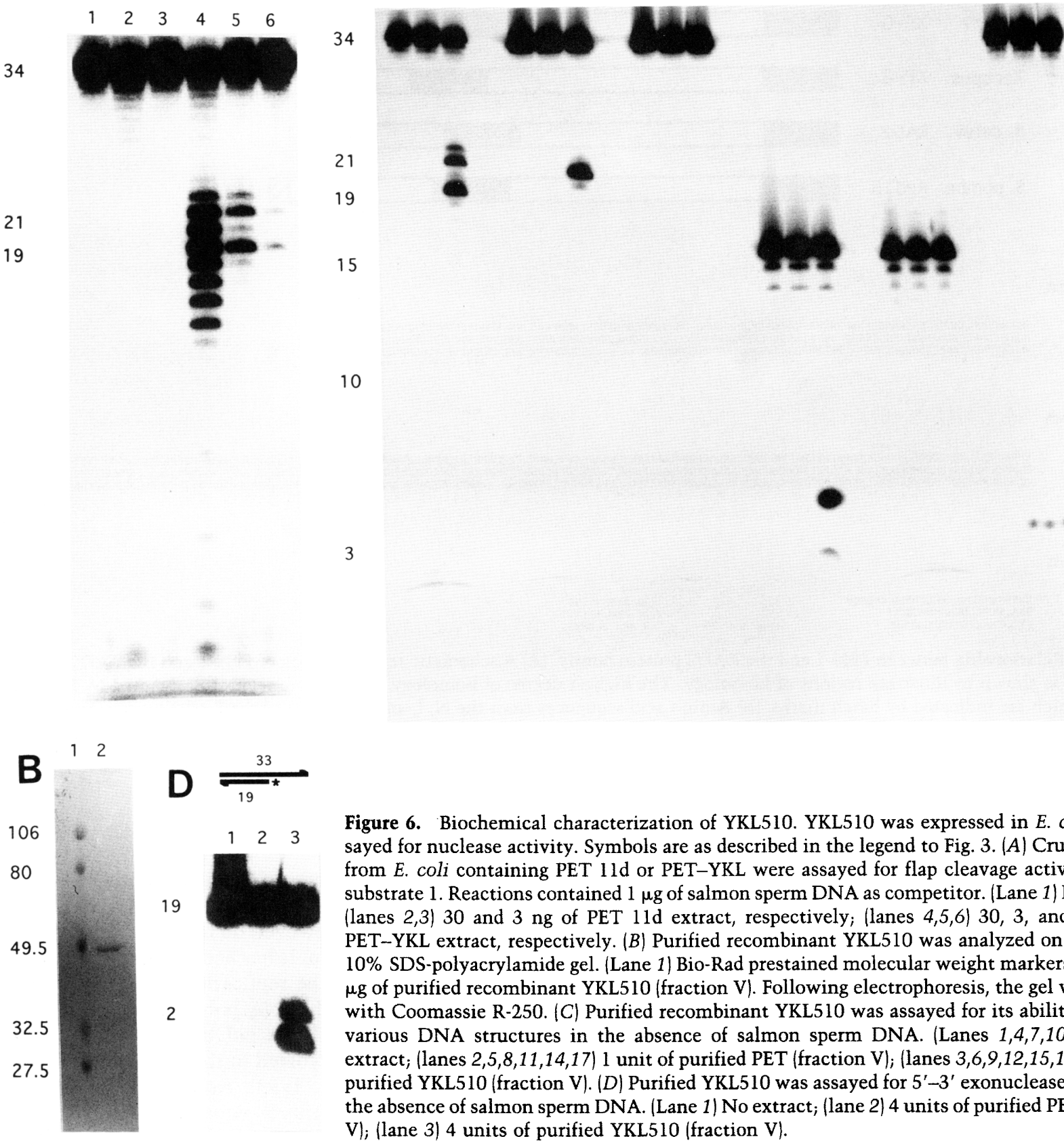

Figure 6. Biochemical characterization of YKL510. YKL510 was expressed in $E$. coli and assayed for nuclease activity. Symbols are as described in the legend to Fig. 3. $(A)$ Crude extracts from $E$. coli containing PET $11 \mathrm{~d}$ or PET-YKL were assayed for flap cleavage activity on flap substrate 1. Reactions contained $1 \mu \mathrm{g}$ of salmon sperm DNA as competitor. (Lane 1) No extract; (lanes 2,3) 30 and $3 \mathrm{ng}$ of PET $11 \mathrm{~d}$ extract, respectively; (lanes 4,5,6) 30, 3, and $0.3 \mathrm{ng}$ of PET-YKL extract, respectively. $(B)$ Purified recombinant YKL510 was analyzed on a reducing $10 \%$ SDS-polyacrylamide gel. (Lane 1) Bio-Rad prestained molecular weight markers; (lane 2) 1 $\mu \mathrm{g}$ of purified recombinant YKL510 (fraction V). Following electrophoresis, the gel was stained with Coomassie R-250. (C) Purified recombinant YKL510 was assayed for its ability to cleave various DNA structures in the absence of salmon sperm DNA. (Lanes $1,4,7,10,13,16)$ No extract; (lanes 2,5,8,11,14,17) 1 unit of purified PET (fraction V); (lanes $3,6,9,12,15,18) 1$ unit of purified YKL510 (fraction V). (D) Purified YKL510 was assayed for $5^{\prime}-3^{\prime}$ exonuclease activity in the absence of salmon sperm DNA. (Lane 1) No extract; (lane 2) 4 units of purified PET (fraction V); (lane 3) 4 units of purified YKL510 (fraction V).

plemented by YKL510. That is, RAD2-deficient $S$. cerevisiae cells, which have a repair deficit of 5 orders of magnitude (Higgins et al. 1984; Naumovski and Friedberg 1984), have normal levels of YKL510. In this study, we have begun to dissect the functional domains of RAD2. We have shown that deletion of the spacer region of RAD2 does not destroy its nuclease activity. This in- dicates that the nuclease active site is either in the N, I, or $\mathrm{C}$ regions. Given the similar structure of $\triangle \mathrm{RAD} 2$ and YKL510, it is likely that $\triangle$ RAD2 will not complement the rad2 mutant phenotype. If this is true, it suggests that the $\mathrm{S}$ region is important for the repair activity of RAD2. As mentioned above, there is increasing evidence for the presence of a multiprotein repair complex involv- 
ing many of the RAD proteins (Bailly et al. 1992; Feaver et al. 1993; van Vuuren et al. 1993; Bardwell et al. 1994). One likely function of the $S$ region, therefore, may be that it participates in protein-protein interactions with other RAD proteins. These interactions may result in the localization of RAD2 to the site of damage.

The localization of RAD2 to the site of damage, however, does not appear to be sufficient for DNA incision to occur. RAD2 is inactive on damaged and undamaged double-stranded DNA (Habraken et al. 1993). This sug. gests that it requires the action of other RAD proteins to set up a DNA structure that it can recognize and cleave. Current models predict that RAD3 and/or RAD25 helicase action at the site of damage generates singlestranded regions of DNA that can then be cleaved by RAD1/10 and RAD2. Our studies with $\triangle \mathrm{RAD} 2$ strongly suggest that single-stranded DNA is not recognized by RAD2, but instead, 5' DNA flap structures and $5^{\prime}$ pseudo-Y structures are its preferred substrate. Although we cannot rule out that we have destroyed one activity of RAD2 (the single-strand endonuclease) and created a new activity (the structure-specific endonuclease), this is unlikely given the strong sequence homology to two other structure-specific endonucleases, FEN-1 and YKL510. It is, therefore, reasonable to apply the specificities of $\triangle R A D 2$ to mechanistic questions about NER.

On the basis of the enzymatic activities of $\triangle \mathrm{RAD} 2$ described here, we propose that RAD2 does not recognize single-stranded DNA per se but, instead, recognizes precise branched DNA structures. Furthermore, the orientation-specific cleavage of these structures by $\triangle R A D 2$ has enabled us to predict the placement of DNA scissions by RAD2 relative to the damaged base(s) (Fig. 8). In our model, we predict that helicase action by RAD3 and/ or RAD25 sets up a single-stranded bubble near the site of damage. The single-stranded bubble is flanked by a $3^{\prime}$ and a $5^{\prime}$ pseudo-Y structure on the $5^{\prime}$ and $3^{\prime}$ side of the damaged base, respectively. A nuclease that cleaves on the $5^{\prime}$ side of the damaged base would be expected to cleave either single-stranded DNA or $3^{\prime}$ pseudo-Y structures. Conversely, a nuclease that cleaves on the $3^{\prime}$ side of the damage should cleave either single-stranded DNA or $5^{\prime}$ pseudo-Y structures. The inability of $\triangle \mathrm{RAD} 2$ to cleave 3 ' pseudo-Y structures or single-stranded DNA and its ability to cleave 5 ' pseudo-Y structures, therefore, indicates that RAD2 cleaves the damaged strand on the 3 ' side of the damage. Presumably, the RADl/10 endonuclease, which is also required for the incision of damaged DNA, cleaves the damaged strand on the $5^{\prime}$ side of the damage. Genetic studies of RAD1/10 are consistent with this prediction (Fishman and Haber 1992). By analogy, the placement of DNA scissions by XP-G, the human analog of RAD2, is likely to be the same.

The determination of the cleavage position of RAD2 and RAD1/10 has important implications in NER. With the recent identification of interactions between the RAD proteins, this result allows one to determine the orientation of the repair complex at the site of damage. Knowledge of this orientation will be important for answering future mechanistic questions about this process.
In addition, this work suggests that specific branched DNA structures are important intermediates in this reaction. Until now, the DNA enzymology of DNA flap structures has been limited by the lack of purified or cloned components. The cloning and characterization of this family of structure-specific endonucleases will facilitate rapid progress in studies of their multiple roles in replication and repair.

\section{Materials and methods}

\section{Cloning of FEN-1 and YKL510}

Tryptic fragments from 35 pmoles of FEN-1 (as determined by amino acid analysis) were HPLC purified and sequenced (Aebersold et al. 1987). Degenerate oligonucleotides HI53 and HI54 were designed, $5^{\prime}$-end-labeled with $\left[\gamma^{32} \mathrm{P}\right] \mathrm{ATP}$, and hybridized to $\lambda Z A P$ phage plaques containing a mouse thymocyte cDNA library (Sambrook et al. 1989). Positives were plaque purified and converted to plasmids according to the manufacturer's instructions (Stratagene). PstI and PvuII restriction fragments of the largest clone, designated pBS-FEN, were ligated into pBluescript to form overlapping subclones. Each subclone was then sequenced on both strands (Sanger et al. 1977). Alignment of FEN-1 with related genes was carried out by use of the Blast server (Altschul et al. 1990).

\section{Construction of $\mathrm{E}$. coli expression vectors}

$F E N-1$ was liberated from pBS-FEN by digestion with $N c o$ and $B a m H I$ and cloned directionally into the $\mathrm{Ncol}$ and BamHI sites of PET 11d (Studier et al. 1990) to create PET-FEN. YKL510 was cloned from $S$. cerevisiae genomic DNA by PCR with primers HJ60 and HJ61. Primer HJ60 created an Ncol site at the ATG translation start of $Y K L 510$, which allowed the PCR product to be cloned into the NcoI site of PET 1ld to create PET-YKL. $R A D 2$ was subcloned from pNF2000 (Naumovski and Friedberg $1984)$ into the Sall site of pBluescript to create pBS-RAD2. $R A D 2$ was amplified by PCR from pBS-RAD2 using primers $\mathrm{HJ} 62$ and VBSK1. These primers created an Ncol site at the ATG translation start of RAD2 allowing the PCR product to be cloned directionally into the NcoI and BamHI sites of PET $11 \mathrm{~d}$ to create PET-RAD2. PET- $\triangle$ RAD2 was created by deleting the region between the NcoI site and the Sful site in PET-RAD2 and replacing it with the $\mathrm{N}$ region of $R A D 2$, which was PCR amplified from pBS-RAD2 with primers HJ62 and HJ63.

\section{Overproduction of enzymes and extract preparation}

PET-FEN, PET-YKL, PET-RAD2, PET- $R$ RAD2, and PET 11d were transformed separately into the $E$. coli strain BL21 (DE3) (Studier et al. 1990) by electroporation and plated onto LB plates containing $100 \mu \mathrm{g} / \mathrm{ml}$ of ampicillin. Colonies from each transformation were inoculated into 2 liters of LB containing 100 $\mu \mathrm{g} / \mathrm{ml}$ of ampicillin. The culture was shaken at $37^{\circ} \mathrm{C}$ until the $\mathrm{OD}_{600}=0.8$ and then induced with $0.5 \mathrm{~mm}$ IPTG for $2 \mathrm{hr}$. Following induction, cells were harvested by centrifugation, resuspended in $40 \mathrm{ml}$ of buffer A $150 \mathrm{~mm}$ Tris at $\mathrm{pH} 8.5,50 \mathrm{~mm}$ $\mathrm{NaCl}$, and lysed by sonication. Lysates were cleared by centrifugation at $25,000 \mathrm{~g}$ and assayed for flap cleavage.

\section{Enzyme purifications}

FEN-1 was purified from 2 liters of E. coli, BL21(DE3), contain- 

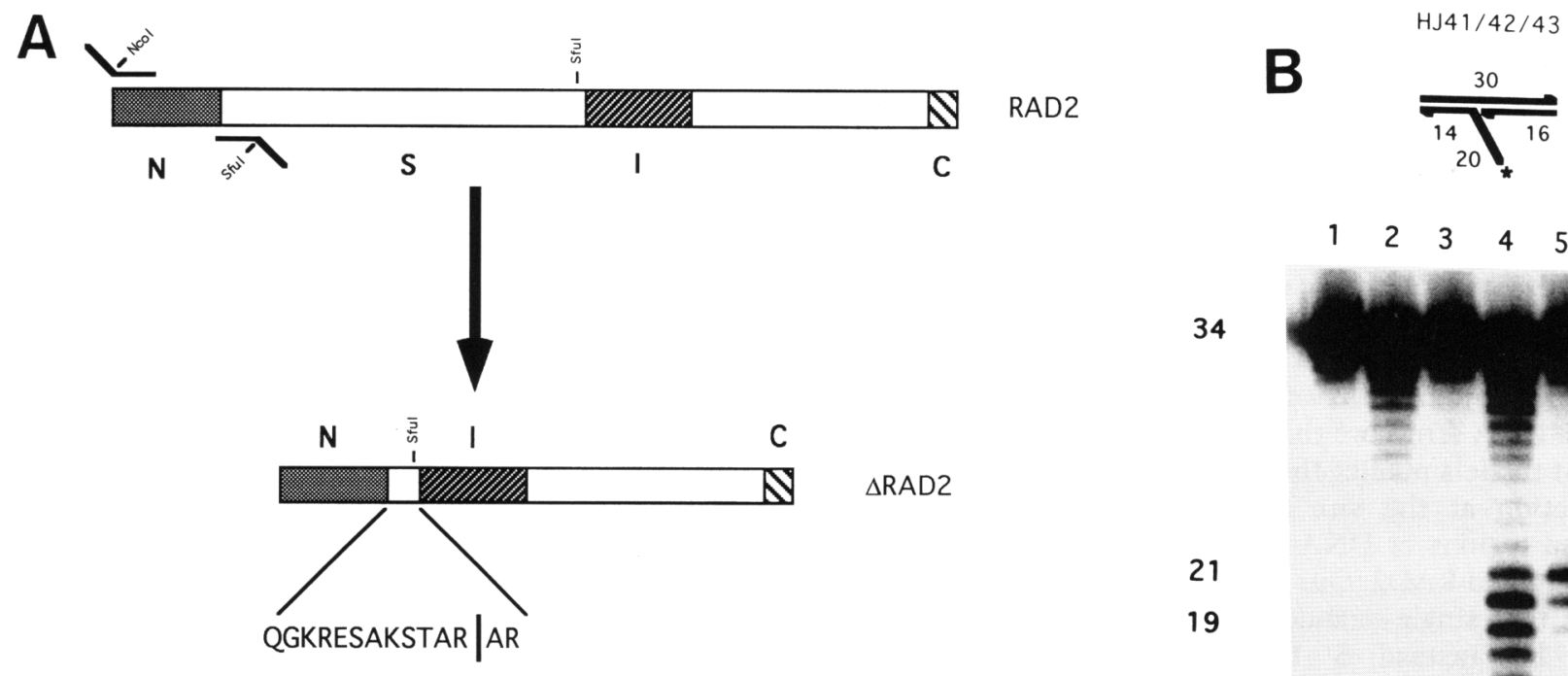

34

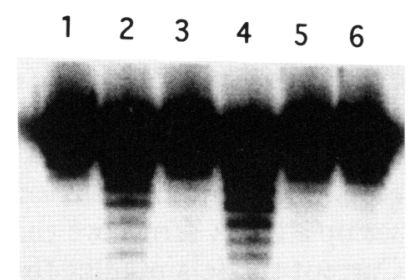

21

19

C

HJ41/42/43

$\mathrm{SC} 1 / 3 / 5$

$\mathrm{SC} 3 / 5$

$\mathrm{SC} 1 / 3 / 4$

HJ39/40/41

HJ42
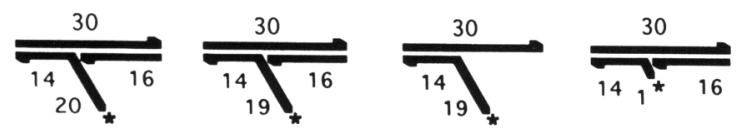

$\frac{30}{\sqrt[18]{5^{10}}}$ *

34

123

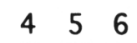

$\begin{array}{lll}7 & 8 & 9\end{array}$

101112

$13 \quad 14 \quad 15$

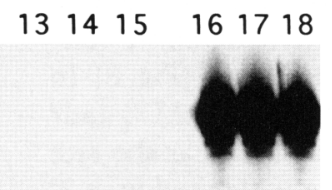

20

15
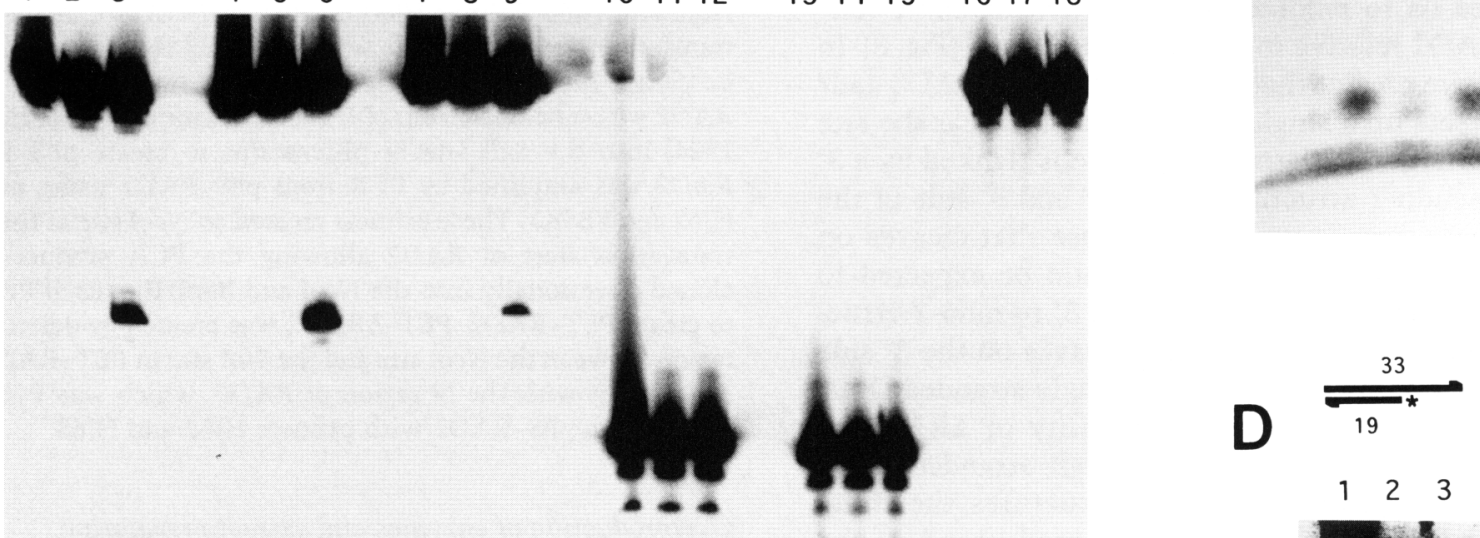

$$
\begin{array}{lll}
1 & 2 & 3
\end{array}
$$

19

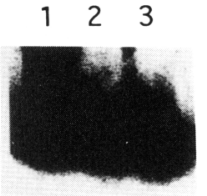

2

3

Figure 7. (See facing page for legend.) 
A

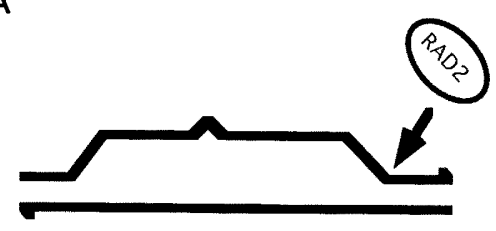

B

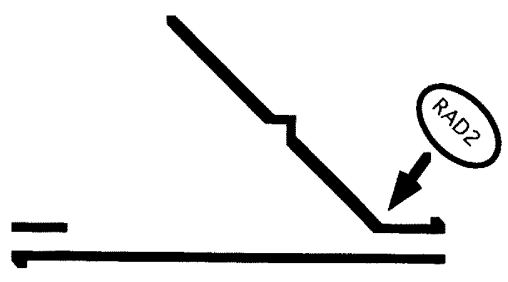

c

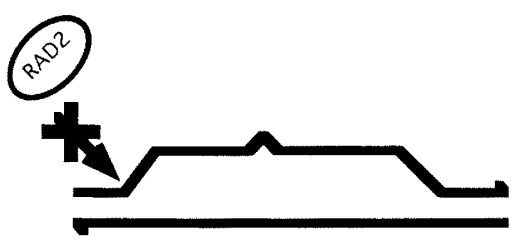

D

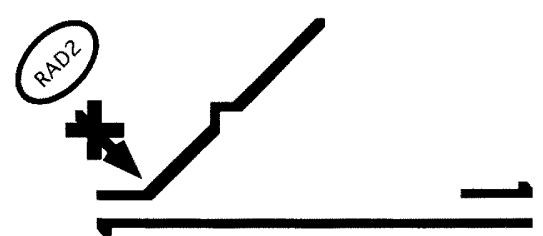

Figure 8. A model for the placement of DNA scission by RAD2. DNA strands are illustrated schematically with the 3 ' end indicated by a half arrow. The damaged nucleotide(s) is indicated by a kink in the top strand. Following recognition, the damaged region is unwound by helicase action, presumably by RAD3 or RAD25. Following unwinding, a single-stranded bubble is formed. Depending on whether RADl/10 cleaves before or after RAD2, one of two structures is formed. In $A$ and $B$, both structures, the single-stranded bubble and the $5^{\prime}$ pseudo-Y structure, have the same polarity and would be cleaved by RAD2. In $C$ and $D$, the polarity of the structures at the $5^{\prime}$ side of the damage is that of a $3^{\prime}$ pseudo-Y structure and, therefore, would not be cleaved by RAD2. ing the FEN-1 expression vector PET-FEN. The crude extract from these cells was prepared as described above and loaded onto a DEAE-Sepharose column $(2.6 \times 8 \mathrm{~cm}, 30 \mathrm{ml})$. The flowthrough was collected and loaded directly onto a heparinSepharose column $(1.6 \times 4 \mathrm{~cm}, 6 \mathrm{ml})$. The column was washed with buffer B (50 mM Tris at $\mathrm{pH} 7.4)$ containing $200 \mathrm{~mm} \mathrm{NaCl}$, and FEN-1 was eluted with buffer B containing $400 \mathrm{~mm} \mathrm{NaCl}$. The heparin-Sepharose pool $(25 \mathrm{ml})$ was diluted with $50 \mathrm{ml}$ of buffer $\mathrm{C}(20 \mathrm{mM} \mathrm{KP}$ at $\mathrm{pH} 7,5 \mathrm{~mm}$ EDTA) and loaded onto a denatured DNA agarose column $(1.6 \times 3 \mathrm{~cm}, 5 \mathrm{ml})$. Following loading, the column was washed with buffer $\mathrm{C}$ and developed with a linear gradient from 0 to $600 \mathrm{mM} \mathrm{KCl}$ in buffer $\mathrm{C}$. Active fractions were pooled and diluted with $30 \mathrm{ml}$ of buffer $\mathrm{D} / 50 \mathrm{~mm}$ Tris at $\mathrm{pH} 9.5$ ) and loaded onto a Mono S HR 5/5 column. FEN-1 was eluted with a gradient from $0-600 \mathrm{~mm} \mathrm{NaCl}$ in buffer $\mathrm{D}$. Active fractions were pooled and loaded directly onto a hydroxylapatite column $(1.6 \times 3 \mathrm{~cm}, 5 \mathrm{ml})$, which was subsequently developed with a gradient from 5 to $350 \mathrm{mM} \mathrm{KP}$ at $\mathrm{pH}$ 7. The hydroxylapatite fractions containing FEN-1 activity were pooled and labeled purified recombinant FEN-1 (fraction V).

YKL510 and $\triangle \mathrm{RAD} 2$ were purified from $E$. coli by use of the same procedure as FEN-1 and were found to behave similarly to FEN-1 at each chromatographic step. Purified YKL510 and $\triangle \mathrm{RAD} 2$ from the hydroxylapatite column are designated fraction V. As a control, extracts from $E$. coli cells containing PET $11 \mathrm{~d}$ were prepared and purified exactly as done for YKL510 and $\triangle \mathrm{RAD} 2$. At each column, fractions corresponding to active fractions in the YKL510 or $\triangle$ RAD2 purifications were pooled. The final purified material was found to be devoid of detectable nuclease activity and is designated purified PET (fraction V).

\section{Nuclease assays}

The standard flap cleavage assay was performed as described previously (Harrington and Lieber 1994). Briefly, oligonucleotide HJ42 was phosphorylated with $\left[\gamma^{32} \mathrm{P}\right]$ ATP and annealed to oligonucleotides HJ41 and HJ43 to produce flap substrate 1 . Reactions contained $10 \mathrm{fmoles}$ of flap substrate 1 in $15 \mu \mathrm{l}$ of $50 \mathrm{~mm}$ Tris (pH 8), $10 \mathrm{~mm} \mathrm{MgCl}, 100 \mu \mathrm{g} / \mathrm{ml}$ of BSA, and the indicated amount of extract or enzyme. Following incubation at $30^{\circ} \mathrm{C}$ for $30 \mathrm{~min}$, the reaction was terminated by the addition of $15 \mu \mathrm{l}$ of $95 \%$ formamide, $1 \mathrm{mg} / \mathrm{ml}$ of bromophenol blue, and $1 \mathrm{mg} / \mathrm{ml}$ of xylene cyanole and then heated to $95^{\circ} \mathrm{C}$ for $5 \mathrm{~min}$. Products were separated on a $15 \%$ denaturing polyacrylamide gel $17 \mathrm{M}$ urea) and visualized on a PhosphorImager. One unit of nuclease activity is defined as the amount of enzyme required to cleave 1 fmole of substrate under standard assay conditions. For FEN-1, YKL510, or $\triangle \mathrm{RAD} 2,1$ unit of flap cleavage activity $\cong 0.1 \mathrm{ng}$ of purified protein.

The exonuclease assay was performed as described previously (Harrington and Lieber 1994). Briefly, oligonucleotide SC6 was phosphorylated with $\left[\gamma^{32} \mathrm{P}\right] \mathrm{ATP}$ and annealed to oligonucleotide SC5. The annealed oligonucleotide substrate was purified on a $15 \%$ native acrylamide gel to remove all unincorporated label. Reactions were performed as in the standard flap assay; however, flap substrate 1 was replaced with $\mathrm{SC} 5 / 6$, and the concentration of $\mathrm{MgCl}_{2}$ was $0.1 \mathrm{~mm}$. The enzyme units indicated in the legend to each figure were determined in the flap endonuclease assay.

\section{Oligonucleotides}

Oligonucleotides were purchased from Operon Technologies

Figure 7. Biochemical characterization of $\triangle \mathrm{RAD} 2$. (A) The $\mathrm{S}$ region of $R A D 2$ was deleted to create a truncated $R A D 2$ molecule, termed $\triangle R A D 2$. A schematic diagram is shown to illustrate the structure of $\triangle R A D 2$. Amino acid sequence is shown at the cloning junctions. The sequence left of the vertical line was derived from amino acids that flank the $\mathrm{N}$ region, while the sequence right of the vertical line was derived from the flank of the I region. $(B)$ Crude extracts from $E$. coli containing PET $11 \mathrm{~d}$ or PET- $\triangle \mathrm{RAD} 2$ were assayed for flap cleavage activity on flap substrate 1 . Reactions contained $1 \mu \mathrm{g}$ of salmon sperm DNA as competitor. (Lane 1 No extract; (lanes 2 and 3) 60 and 12 ng of PET 11d extract, respectively; (lanes 4,5,6) 60, 12, and 2.4 ng of PET- $\triangle R A D 2$ extract, respectively. (C) Purified recombinant $\triangle \mathrm{RAD} 2$ was assayed for its ability to cleave various DNA structures in the absence of salmon sperm DNA. Symbols are as described in the legend to Fig. 3. (Lanes $1,4,7,10,13,16$ ) No extract; (lanes 2,5,8,11,14,17) 1 unit of PET (fraction V); (lanes $3,6,9,12,15,18) 1$ unit of $\triangle \mathrm{RAD} 2$ (fraction V). (D) Purified $\triangle \mathrm{RAD} 2$ was assayed for $5^{\prime}-3^{\prime}$ exonuclease activity in the absence of salmon sperm DNA. (Lane 1) No extract; (lane 2) 4 units of PET fraction V; (lane 3) 4 units of $\triangle R A D 2$ fraction V. 
(Alameda, CA) and are shown 5'-3'. HI39, CACGTTGACTGAATC; HJ40, ACCGTCTTGAGGCAGAGT; HJ41, GGACTCTGCCTCAAGACGGTAGTCAACGTG; HJ42, GATGTCAAGCAGTCCTAACTTTGAGGCAGAGTCC; HJ43, CACGTTGACTACCGTC; HJ53, CAGGGIMGICTIGATGACTTCTTCAARGTIAC; HI54, GAYGAYTTYTTYAARGT; HJ60, CAACCTGCAGAACCATGGGTATTAAAGGTTTGAATGCAATTATATCG; HJ61， GAACCTGCAGCCATGGTGGAAAAAGAACCCCCTCATCTTCTTCCC; HJ62, TTTTCTGCAGCCATGGGTGTGCATCATTTTGGG; HJ63, GGGGCTGCAGTTCGAACCTAGCGGTGGATTTCGCACTC; VBSK1, GCGCAATTAACCCTCACTAAAGGGAAC. Inosine is indicated with $\mathrm{I}$, and the degenerate positions corresponding to $\mathrm{A}$ or $G$, $C$ or $A$, and $C$ or $T$ are indicated with $R, M$, and $Y$, respectively.

\section{Generation of FEN-1 antibodies}

Purified recombinant FEN-1 $1500 \mu \mathrm{g}$ of fraction V in RIBI adjuvant) was injected subcutaneously into $5-\mathrm{kg}$ New Zealand white rabbits. At 21 and 60 days postprimary injection, the rabbits were boosted with $250 \mu \mathrm{g}$ of FEN-1 fraction V in RIBI adjuvant. Serum was collected 8 days following each boost. The IgG fraction was purified from the serum on protein A-Sepharose (Pharmacia LKB, Inc.) according to the manufacturer's instructions. Control antiserum and IgG were collected and purified from rabbits, which were injected with an unrelated protein called RAG-1 by use of the same procedure as described above for FEN-1.

\section{SDS.PAGE and western blotting}

Proteins were analyzed on $10 \%$ SDS-polyacrylamide gels and visualized by staining with Coomassie G-250 or silver. Western blotting was carried out with FEN-1 antiserum at a 1:500 dilution.

\section{Acknowledgments}

We thank Louie Naumovski for generously providing us with the $R A D 2$ gene. We thank the members of our laboratory for helpful discussions and critical reading of this manuscript. This work is supported by National Institutes of Health grants to M.R.L. and, in part, by a grant from the Lucille P. Markey Charitable Trust. M.R.L. is also a Cancer Research Institute Investigator. J.J.H. was supported by U.S. Public Health Service grant 5T32CA09302 awarded by the National Cancer Institute through the Program in Cancer Biology. The nucleotide sequence of the murine FEN-1 cDNA will appear in the EMBL, GenBank, and DDBJ nucleotide sequence data bases under the accession number L26320.

The publication costs of this article were defrayed in part by payment of page charges. This article must therefore be hereby marked "advertisement" in accordance with 18 USC section 1734 solely to indicate this fact.

\section{Note added in proof}

Our laboratory has cloned and purified the human FEN-1, in addition to the murine FEN-1 and yeast FEN-1 (also known as YKL510). The Stillman laboratory has purified an enzyme called MF-1 that is essential for cell-free SV40 DNA replication in the joining of Okazaki fragments on the lagging strand $[/ \mathrm{Biol}$ Chem. 269: 10923-10934 (1994); Nature (1994, in press)]. The sequences of unpublished peptide fragments of MF-1 /S. Waga, R. Kobayashi, and B. Stillman) are present in the translated se- quence from our human FEN-1 clone. Hence, FEN-1 and MF-1 are almost certain to be the same.

\section{References}

Aebersold, R.H., J. Leavitt, R.A. Saavedra, and L.E. Hood. 1987. Internal amino acid sequence analysis of proteins separated by one- or two-dimensional gel electrophoresis after in situ protease digestion on nitrocellulose. Proc. Natl. Acad. Sci. 84: 6970-6974

Altschul, S.F., W. Gish, W. Miller, E.W. Myers, and D.J. Lipman. 1990. Basic local alignment search tool. J. Mol. Biol. 215: 403-410.

Bailly, V., C.H. Sommers, P. Sung, L. Prakash, and S. Prakash. 1992. Specific complex formation between proteins encoded by the yeast DNA repair and recombination genes RAD1 and RAD10. Proc. Natl. Acad. Sci. 89: 8273-8277.

Baker, T. and A. Kornberg. 1992. DNA replication, 2nd ed. W.H. Freeman and Company, New York.

Bardwell, L., A.J. Cooper, and E.C. Friedberg. 1992. Stable and specific association between the yeast recombination and DNA repair proteins RADl and RADI0 in vitro. Mol. Cell. Biol. 12: 3041-3049.

Bardwell, L., J. Bardwell, W. Feaver, J. Svejstrup, R. Kornberg, and E. Friedberg. 1994. Yeast RAD3 protein binds directly to both Ssl2 and Ssll proteins: Implications for the structure and function of transcription/repair factor b. Proc. Natl. Acad. Sci. (in press).

Carr, A.M., K.S. Sheldrick, J.M. Murray, R. Al-Harithy, F.Z. Watts, and A.R. Lehmann. 1993. Evolutionary conservation of excision repair in Schizosaccharomyces pombe: Evidence for a family of sequences related to the Saccharomyces cerevisiae RAD2 gene. Nucleic Acids Res. 21: 1345-1349.

Feaver, W., J. Svejstrup, L. Bardwell, J. Bardwell, S. Buratowski, K. Gulyas, T. Donahue, E. Friedberg, and R. Kornberg. 1993. Dual roles of a multiprotein complex from $S$. cerevisiae in transcription and DNA repair. Cell 75: 1-20.

Fishman, L.J. and J.E. Haber. 1992. Removal of nonhomologous DNA ends in double-strand break recombination: The role of the yeast ultraviolet repair gene RAD1. Science 258: 480484.

Gulyas, K.D. and T.F. Donahue. 1992. SSL2, a suppressor of a stem-loop mutation in the HIS4 leader encodes the yeast homolog of human ERCC-3. Cell 69: 1031-1042.

Guzder, S.N., P. Sung, L. Prakash, and S. Prakash. 1993. Yeast DNA-repair gene RAD14 encodes a zinc metalloprotein with affinity for ultraviolet-damaged DNA. Proc. Natl. Acad. Sci. 90: 5433-5437.

Habraken, Y., P. Sung, L. Prakash, and S. Prakash. 1993. Yeast excision repair gene $R A D 2$ encodes a single-stranded DNA endonuclease. Nature 366: 365-368.

Harosh, I., L. Naumovski, and E.C. Friedberg. 1989. Purification and characterization of $\operatorname{Rad} 3$ ATPase/DNA helicase from Saccharomyces cerevisiae. J. Biol. Chem. 264: 20532-20539.

Harrington, J.J. and M.R. Lieber. 1994. The characterization of a mammalian DNA structure-specific endonuclease. $E M B O J$. 13: 1235-1246.

Higgins, D.R., L. Prakash, P. Reynolds, and S. Prakash. 1984. Isolation and characterization of the RAD2 gene of Saccharomyces cerevisiae. Gene 30: 121-128.

Jacquier, A., P. Legrain, and B. Dujon. 1992. Sequence of a 10.7 kb segment of yeast chromosome XI identifies the $A P N I$ and the $B A F 1$ loci and reveals one tRNA gene and several new open reading frames including homologs to RAD2 and kinases. Yeast 8: 121-132.

Lehmann, A.R., A.M. Carr, F.Z. Watts, and J.M. Murray. 1991. 
DNA repair in the fission yeast, Schizosaccharomyces pombe. Mutat. Res. 250: 205-210.

Lyamichev, V., M.A. Brow, and J.E. Dahlberg. 1993. Structurespecific endonucleolytic cleavage of nucleic acids by eubacterial DNA polymerases. Science 260: 778-783.

MacInnes, M.A., J.A. Dickson, R.R. Hernandez, D. Learmonth, G.Y. Lin, J.S. Mudgett, M.S. Park, S. Schauer, R.J. Reynolds, G.R. Strniste, and J.Y. Yu. 1993. Human ERCC5 cDNAcosmid complementation for excision repair and bipartite amino acid domains conserved with RAD proteins of Saccharomyces cerevisiae and Schizosaccharomyces pombe. Mol. Cell. Biol. 13: 6393-6402.

Murante, R., L. Huang, J. Turchi, and R. Bambara. 1994. The calf $5^{\prime}$ to $3^{\prime}$ exonuclease is also an endonuclease with both activities dependent on primers annealed upstream of the point of cleavage. J. Biol. Chem. 269: 1191-1196.

Naumovski, L. and E.C. Friedberg. 1984. Saccharomyces cerevisiae $R A D 2$ gene: Isolation, subcloning, and partial characterization. Mol. Cell. Biol. 4: 290-295.

Park, E., S.N. Guzder, M.H. Koken, D.I. Jaspers, G. Weeda, J.H. Hoeijmakers, S. Prakash, and L. Prakash. 1992. RAD25 (SSL2), the yeast homolog of the human xeroderma pigmentosum group B DNA repair gene, is essential for viability. Proc. Natl. Acad. Sci. 89: 11416-11420.

Prakash, S., P. Sung, and L. Prakash. 1993. DNA repair genes and proteins of Saccharomyces cerevisiae. Annu. Rev. Genet. 27: 33-70.

Sambrook, J., E.F. Fritsch, and T. Maniatis. 1989. Molecular cloning, 2nd ed. Cold Spring Harbor Laboratory Press, Cold Spring Harbor, New York.

Sanger, F., S. Nicklen, and A.R. Coulson. 1977. DNA sequencing with chain-terminating inhibitors. Proc. Natl. Acad. Sci. 74: 5463-5467.

Scherly, D., T. Nouspikel, J. Corlet, C. Ucla, A. Bairoch, and S.G. Clarkson. 1993. Complementation of the DNA repair defect in xeroderma pigmentosum group $\mathrm{G}$ cells by a human cDNA related to yeast RAD2. Nature 363: 182-185.

Siegal, G., J.J. Turchi, T.W. Myers, and R.A. Bambara. 1992. A 5' to $3^{\prime}$ exonuclease functionally interacts with calf DNA polymerase epsilon. Proc. Natl. Acad. Sci. 89: 9377-9381.

Studier, F.W., A.H. Rosenberg, J.J. Dunn, and J.W. Dubendorff. 1990. Use of T7 RNA polymerase to direct expression of cloned genes. Methods Enzymol. 185: 60-89.

Sung, P., L. Prakash, S.W. Matson, and S. Prakash. 1987. RAD3 protein of Saccharomyces cerevisiae is a DNA helicase. Proc. Natl. Acad. Sci. 84: 8951-8955.

Tomkinson, A.E., A.J. Bardwell, L. Bardwell, N.J. Tappe, and E.C. Friedberg. 1993. Yeast DNA repair and recombination proteins Radl and Rad10 constitute a single-stranded-DNA endonuclease. Nature 362: 860-862.

van Vuuren, A.J., E. Appeldoorn, H. Odijk, A. Yasui, N.G. Jaspers, and J.H. Hoeijmakers. 1993. Evidence for a repair enzyme complex involving ERCC1, ERCC4, ERCC11, and the xeroderma pigmentosum group $\mathrm{F}$ proteins. $E M B O \quad I$. 12: 3693-3701.

Wang, Z., X. Wu, and E.C. Friedberg. 1993. DNA repair synthesis during base excision repair in vitro is catalyzed by DNA polymerase epsilon and is influenced by DNA polymerases alpha and delta in Saccharomyces cerevisiae. Mol. Cell. Biol. 13: $1051-1058$. 


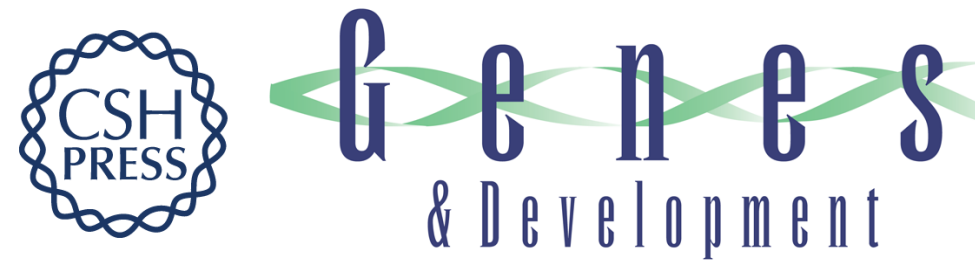

\section{Functional domains within FEN-1 and RAD2 define a family of structure-specific endonucleases: implications for nucleotide excision repair.}

$\mathrm{J} \mathrm{J}$ Harrington and M R Lieber

Genes Dev. 1994, 8:

Access the most recent version at doi:10.1101/gad.8.11.1344

References This article cites 29 articles, 15 of which can be accessed free at:

http://genesdev.cshlp.org/content/8/11/1344.full.html\#ref-list-1

License

Email Alerting Receive free email alerts when new articles cite this article - sign up in the box at the top Service right corner of the article or click here.

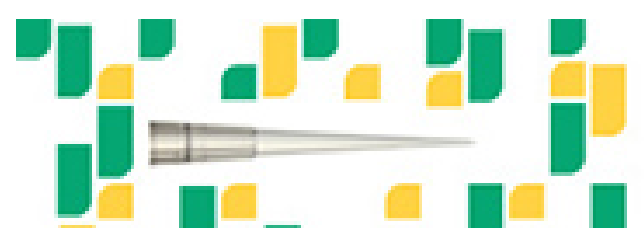

Focused on your science. 